\title{
水ロケットの空力特性と飛行安定化について*1 Aerodynamic Characteristics of Water Rocket and Stabilization of Flight Trajectory
}

\author{
渡 辺力 夫*2 ·冨 田信 之*2 竹 前 俊 昭*3 \\ Rikio Watanabe, Nobuyuki Tomita and Toshiaki Takemae
}

Key Words : Water Rocket, Aerodynamic Characteristics, Robust Design

\begin{abstract}
The aerodynamic characteristics of water rockets are analyzed experimentally by wind tunnel testing. Aerodynamic devices such as vortex generators and dimples are tested and their effectiveness to the flight performance of water rocket is discussed. Attaching vortex generators suppresses the unsteady body fluttering. Dimpling the nose reduces the drag coefficient in high angles of attack. Robust design approach is applied to water rocket design for flight stability and optimum water rocket configuration is determined. Semi-sphere nose is found to be effective for flight stability and it is desirable for the safety of landing point. Stiffed fin attachment is required for fins to work properly as aerodynamic device and it enhances the flight stability of water rockets.
\end{abstract}

\section{1.は じめ に}

水ロケット (Water rocket) は, 高圧 (通常 5 気圧程度) の圧縮空気で水を押し出して推力を得るロケットシステム で, 通常 PET (Poly Ethylene Terephthalate) ボトルを 用いて製作される . 小型で製作も容易であるが，水ロケッ 卜に含まれる技術的な要素や原理は実際のロケットシステ ムと共通の部分が多く, 科学教育・研究用教材として適切 なシステムであるといえる11．

しかし，水ロケットが飛翔体である以上，打ち上げ時の 安全には注意を払う必要がある.水ロケットが指定した軌 道を飛行し, 安全な領域に着地すれば問題ないが, 実際に 水ロケットを作って飛ばしてみると, 光の飛行経路は必ず しも安定しないことが多く，地上の物・人に損傷を与える 可能性がある . パラシュートのような装置を装着して安全 に着地させる方法もあるが，イベント時のように短時間で 製作して打ち上げを行う場合には，簡単な構成の水ロケッ 卜を製作するので, 誰が作っても安定に飛行するような機 体構成を考える必要がある。

著者らはこれまでに, 水ロケットの推力特性を理論的お よび実験的に明らかにし，ボトル内の水流の乱れを押さえ， 飛行の安定に寄与するノズル部の開発を行ってきた ${ }^{2)}$. ま た, 飛行特性を評価するための飛行軌道の数値解析 ${ }^{3)}$ や飛 行軌道計測法の確立 ${ }^{4)}$ も行っている. しかし, 軌道解析を 行う際に必要となる基礎的な空気力学データや, 安定な飛 行を実現する上で重要となる空力設計・構造設計のための

\footnotetext{
*1 (C) 2004 日本航空宇宙学会

平成 15 年 9 月 17 日原稿受理

*2 武蔵工業大学工学部

*3 宇宙航空研究開発機構宇宙科学研究本部
}

指針などは経験的な部分が多く, 定量的な検討を行う必要 があると考え，一連の検討を行ってきた .

本論文では, 水ロケットの空力特性を把握することを目 的として実施した水ロケット模型による風洞試験の結果と， 关の結果に基づいて行った飛行特性の改善に関する検討の 結果を報告する . 風洞試験においては, 空力特性の取得に 加えて境界層制御 (ヴォルテックス・ジェネレータとディ ンプル) の効果も調ベた . また, 風洞試験の観察より, フィ ン岡性とフィン取り付け剛性のもつ重要性を再認識し, 設 計上の改善を行った .これらの改善効果の確認には, ロバ スト設計の手法を応用した .

ロバスト設計とは，設計パラメータと対象物の品質との 関係を調べ, 光の影響を最小限にする設計手法であるが5,6)， 水ロケットの設計改善評価にも有効である . 本論文では水 ロケットの飛行安定性に影響を与える因子の評価にロバス 卜設計の手法を応用することにとどめたが , より徹底した ロバスト設計の応用を実施中である。

\section{2. 水ロケットの空力係数}

2.1 細長物体理論 水ロケットの空気力は一般的な飛 翔体に利用されている細長物体理論を用いて解析すること ができる．ここでは, 抵抗係数と揚力傾斜に関する解析式 の概略7)を述べ，風洞実験の検証に用いる .

2.1 .1 抵抗係数 水ロケットの抵抗係数はフィンの摩擦 抵抗係数 $C_{\mathrm{Df} 1}$, 機体の摩擦抵抗係数 $C_{\mathrm{Df} 2}$, 機体の形状抵 抗係数 $C_{\mathrm{Db}}$ の和として表される.

$$
C_{\mathrm{D}}=C_{\mathrm{Df} 1}+C_{\mathrm{Df} 2}+C_{\mathrm{Db}}
$$

フィンの摩擦抵抗係数は, フィンの空力平均翼弦を $c$, 翼 の厚さを $t$, 翼面積を $S_{\mathrm{w}}$, 胴体断面積を $S_{\mathrm{B}}$, 摩擦抵抗係 
数を $C_{\mathrm{f}}$ として，以下の式で表される.

$$
C_{\mathrm{Df} 1}=2 C_{\mathrm{f}}\left(1+2 \frac{t}{c}+100\left(\frac{t}{c}\right)^{4}\right) \frac{2 S_{\mathrm{W}}}{S_{\mathrm{B}}}
$$

フィンの空力平均翼弦は翼根における翼弦長を $c_{\mathrm{r}}$, 翼端 における翼弦長を $c_{\mathrm{t}}$, 翼のテーパ比を $\lambda$ として, 以下の式 で表される。

$$
c=\frac{2}{3} c_{\mathrm{r}}\left(1+\frac{\lambda^{2}}{1+\lambda}\right), \quad \lambda=\frac{c_{\mathrm{t}}}{c_{\mathrm{r}}}
$$

機体の摩擦抵抗係数は, 胴体長を $l_{\mathrm{B}}$, 胴体直径を $d$, 胴 体表面積を $S_{\mathrm{S}}$ として，以下の式で表される.

$$
C_{\mathrm{Df} 2}=1.02 C_{\mathrm{f}}\left(1+\frac{1.5}{\left(l_{\mathrm{B}} / d\right)^{3 / 2}}+\frac{7}{\left(l_{\mathrm{B}} / d\right)^{3}}\right) \frac{S_{\mathrm{S}}}{S_{\mathrm{B}}}
$$

機体形状抵抗係数は機体摩擦抵抗係数を用いて, 次式で 計算する。

$$
C_{\mathrm{Db}}=0.029 \frac{\left(d_{\mathrm{b}} / d\right)^{3}}{\sqrt{C_{\mathrm{Df} 2}}}
$$

ただし，

$$
\frac{d_{\mathrm{b}}}{d}=1.0
$$

2.1 .2 揚力傾斜 水ロケットの揚力傾斜は，ノーズ部 の揚力傾斜 $C_{\mathrm{L} \alpha(\mathrm{N})}$, 翼胴干渉を考慮した翼の揚力傾斜 $C_{\mathrm{L} \alpha \mathrm{W}(\mathrm{B})}$, 翼胴干渉を考慮した胴体の揚力傾斜 $C_{\mathrm{L} \alpha \mathrm{B}(\mathrm{W})}$ の和で表される .

$$
C_{\mathrm{L} \alpha}=C_{\mathrm{L} \alpha(\mathrm{N})}+C_{\mathrm{L} \alpha \mathrm{W}(\mathrm{B})}+C_{\mathrm{L} \alpha \mathrm{B}(\mathrm{W})}
$$

ノーズ部の揚力傾斜は $C_{\mathrm{L} \alpha(\mathrm{N})}=2$ とする. 翼胴干渉を 考慮した翼の揚力傾斜は, 翼のアスペクト比を $A_{\mathrm{W}}$, 翼単 体の揚力傾斜を $C_{\mathrm{L} \alpha \mathrm{W}}$ として，以下のように表される.

$$
C_{\mathrm{L} \alpha \mathrm{W}(\mathrm{B})}=H_{\mathrm{W}(\mathrm{B})} \frac{1}{A_{\mathrm{W}}} C_{\mathrm{L} \alpha \mathrm{W}}
$$

ただし, $C_{\mathrm{L} \alpha \mathrm{W}} / A_{\mathrm{W}}=1.6, H_{\mathrm{W}(\mathrm{B})}$ は (胴体半径/翼幅) の 関数で, 文献 7) 中の表から計算した .

翼胴干渉を考慮した胴体の揚力傾斜は，以下のように表 される .

$$
C_{\mathrm{L} \alpha \mathrm{B}(\mathrm{W})}=H_{\mathrm{B}(\mathrm{W})} \frac{1}{A_{\mathrm{W}}} C_{\mathrm{L} \alpha \mathrm{W}}
$$

同樣に, $H_{\mathrm{B}(\mathrm{W})}$ は文献 7)の表から求めた .

2.2 風洞実験8) 水ロケットの飛行速度はボトル内の水 がすべて放出された直後に最大となり，初期圧力が 5 気圧 の場合には約 $25 \mathrm{~m} / \mathrm{s}$ になることか理論的および実験的に 明らかになっている ${ }^{9)}$. 従って, 水ロケットの空力特性を 得るための風洞設備としては低速風洞で十分である . 本実 験では, 東京大学工学部航空宇宙工学科所有の $1.5 \mathrm{~m}$ ゲッ チンゲン型低速風洞を使用して実験を行った .この風洞は 計測部直径が $1.5 \mathrm{~m}$ の回流型 (ゲッチンゲン型) で, 最高 風速は $40 \mathrm{~m} / \mathrm{s}$ であり，本実験には適切な風洞設備である． 試験部は大気開放型で，ワイヤによって模型を支持し，ワ イヤと連結したロードセルによって揚力や抵抗の值を得る．

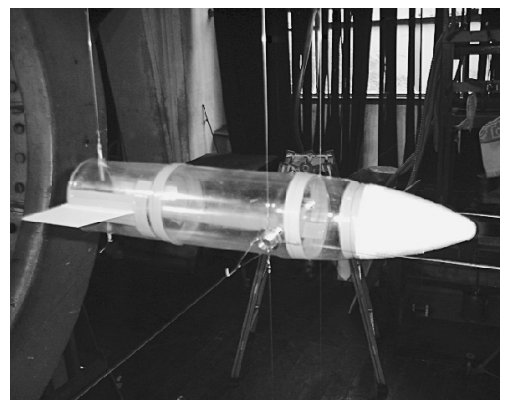

第1图 PET ボトルを使用した風洞模型

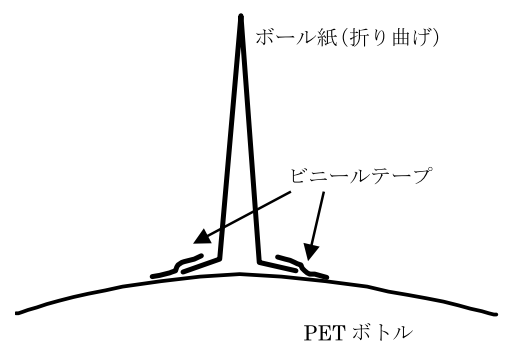

第2図 フィンの取り付け (従来型)

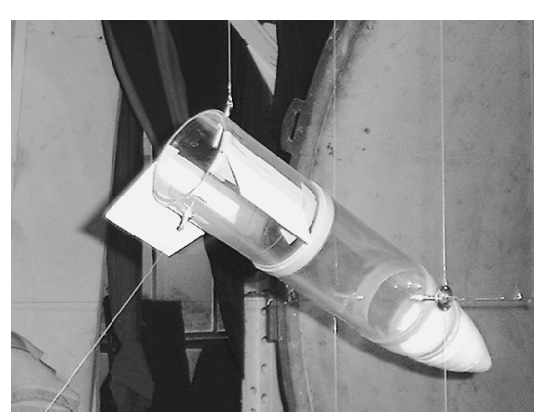

第3図＼cjkstart通風時に折れ曲がったフィン

2.2.1 供試体 供試体としては当初, 通常のイベント等 で用いられる水ロケット光のものを用いた (第 1 図).す なわち，PET ボトルにコーン型ノズルを装着し，フィンは 厚さ $1 \mathrm{~mm}$ のボール紙を折り曲げてビニールテープでボト ル本体に貼り付けた (第 2 図).PET ボトル本体について は，剛性が足りないことから，PET ボトルの内側にアク リル管を挿入して補強した。しかしながら，実験を行った 結果，迎角をつけた状態で風速 $20 \mathrm{~m} / \mathrm{s}$ を越えるとフィン か胴体に沿って曲がり始め, $30 \mathrm{~m} / \mathrm{s}$ になると, フィンとし ての機能が無くなるほど折れ曲がることが判明した（第 3 図) .フィンの作り方と取り付け方法は従来慣習的に用いて きた方法で, フィンの強度や取り付け方法 (取り付け剛性) に関しては特に注意していなかったが, 弚の両方を改善す る必要があることがわかった . 同時に, 風洞試験の供試体 として PET ボトルロケット兴のものを使用することが不 適切であることがわかった . 乥こで, 改めて木材 (桜) で PET ボトルロケットを模した風洞模型を製作した .

ノーズ部の基本形状としては, コーン型と半球型を用意 した . 通常の PET ボトルロケットでは, コーン型のノー 


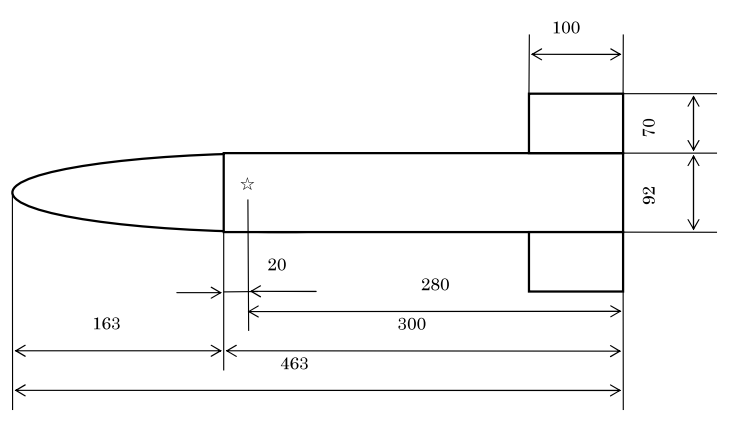

(a) コーン型ノーズ

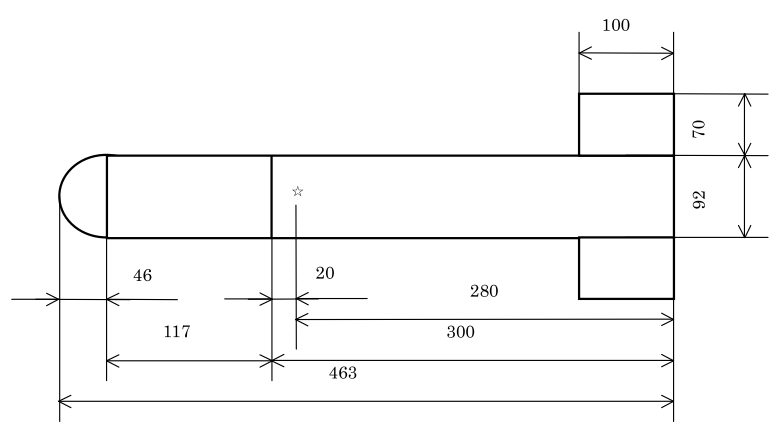

(b) 半球型ノーズ

第 4 図風洞模型概略図

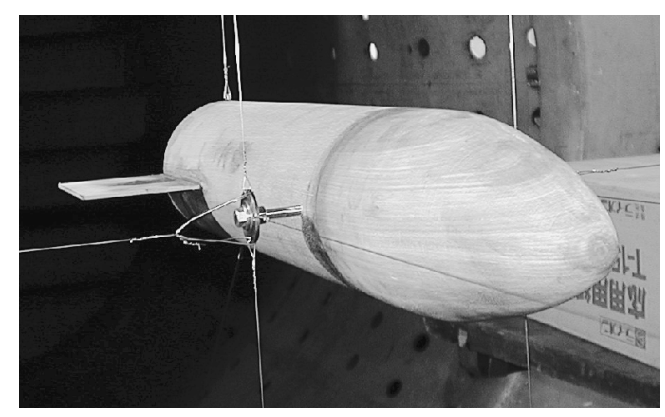

第 5 図 供試体の例（コーン型ノーズ）

ズが使われているが , 着地点の安全性を考えると半球型の 方が好ましいと考えたので, 半球型ノーズも調べることと した . 境界層制御装置としては, ヴォルテックス・ジェネ レータとディンプル (半球型ノーズのみ) をノーズ部に設 けたものを用意し，空力係数への影響を調べた . フィンに ついては, 胴体部に固定して接着した . 実験模型の概略を 第 4 図に示す.第 4 図 (a) はコーン型ノーズを装着した場 合である. 全長 $463 \mathrm{~mm}$, 胴体径 $92 \mathrm{~mm}$ は, 2 つの PET ボトルを用いて製作する水ロケットの寸法である . 第 4 图 (b) は半球型ノーズを装着した場合である . 全長を合わせ るため，胴体部を $117 \mathrm{~mm}$ 延長している，供試体の一例を 第 5 図に示す.

2.2.2 ヴォルテックス・ジェネレータ ヴオルテックス・ ジェネレータは航空機の翼面上などに取り付けられる小さ な突起物で，層流境界層を乱して乱流にすることにより流 れの剝離点を後方に遅らせ , 大迎角時に高揚力を得るため の装置である . 本実験では, 流れ方向の長さ $10 \mathrm{~mm}$, 高さ $10 \mathrm{~mm}$ の塩化ビニール板を合計 16 枚，等間隔に配置した .

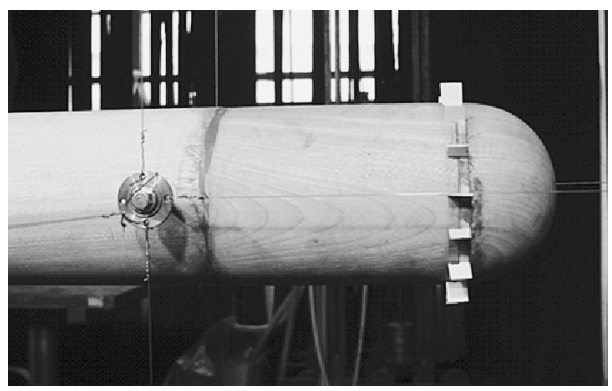

第6图 ヴォルテックス・ジェネレータ (半球型ノーズ)

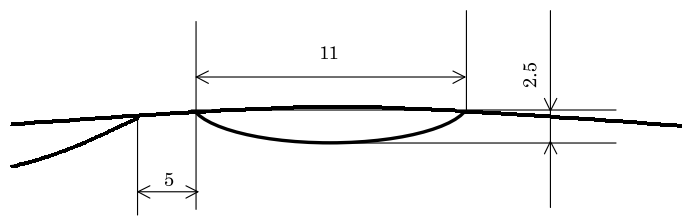

第7図 ディンプルの形状

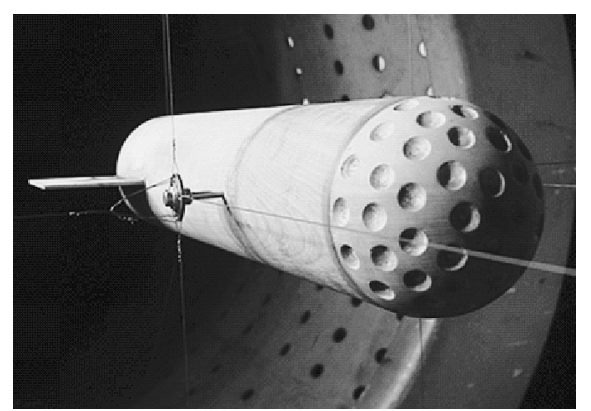

第 8 図 ディンプルを施した供試体

第 1 表 供試体

\begin{tabular}{|c|c|c|c|c|c|}
\hline 供試体番号 & $\# 1$ & $\# 2$ & $\# 3$ & $\# 4$ & $\# 5$ \\
\hline ノーズ形状 & コーン型 & コーン型 & 半球型 & 半球型 & $\begin{array}{l}\text { 半球型 (ディ } \\
\text { ンプル付) }\end{array}$ \\
\hline $\begin{array}{l}\text { ヴォルテックス. } \\
\text { ジェネレータ }\end{array}$ & 無し & 有り & 無し & 有り & 無し \\
\hline
\end{tabular}

設置場所はノーズ部と胴体部の接続部である . 第 6 図にヴオ ルテックス・ジェネレータを装着した供試体の樣子を示す．

2.2.3 ディンプル ディンプルは, ゴルフボールなどの 球形物体に施すと物体周り流れを乱流化し，剝離を遅らせ ることによって抵抗を減少させる効果がある ${ }^{10)}$. 本実験で は, 半球型のノーズ部にディンプルを施し，抵抗減少の効 果があるかを調べた . ディンプル形状は第 7 図に示した通 りで, 直径 $92 \mathrm{~mm}$ の半球径ノーズに対して 48 個の窪みを 規則的に配置した . 第 8 図にディンプルを施した供試体の 樣子を示す。

2.2 .4 実験条件 実験は第 1 表に示した 5 種類の供試体 に対して行った . 水ロケットは水と空気の排出によって推 力を得ている期間 (初期压が 5 気圧の場合，打ち上げ後 $600 \mathrm{~ms}$ まで) に増速し, 产の後は無推力で弾道飛行を行う. また , 光の最高速度は初期圧が 5 気圧の場合には $25 \mathrm{~m} / \mathrm{s}$ 程 度と見積もられている.よって, 試験を行う風速は $10 ， 20 ，$ 


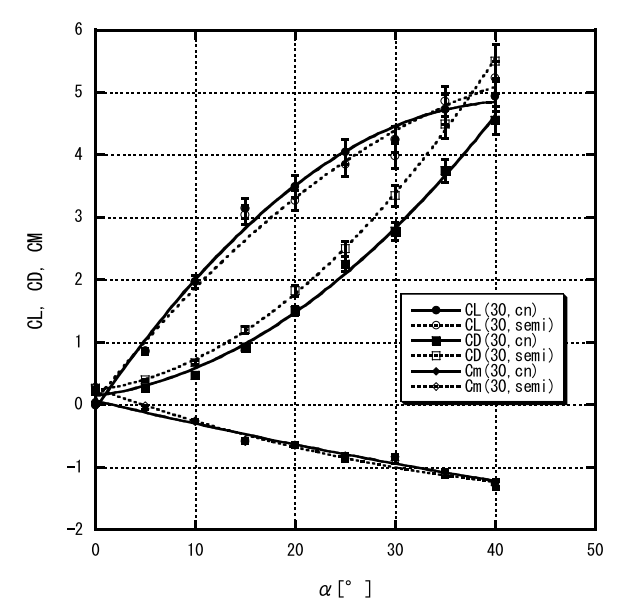

第9図 ノーズ形状による違い

第 2 表 試験風速とレイノルズ数

\begin{tabular}{lccc}
\hline 風速 $(\mathrm{m} / \mathrm{s})$ & 10 & 20 & 30 \\
\hline レイノルズ数 & $3.01 \times 10^{5}$ & $6.02 \times 10^{5}$ & $9.03 \times 10^{5}$ \\
\hline
\end{tabular}

$30 \mathrm{~m} / \mathrm{s}$ とした . 水ロケットの飛行軌道と姿勢は, 飛行安定 性の対策を考慮しないと大きくばらつくことがある．飛行 姿勢のばらつきに加え，横風を受けた場合には相対的な迎 角か増加するので，迎角は $0^{\circ}$ から $40^{\circ}$ までとし， $5^{\circ}$ 間隔 でデータを取得した . 実験室の気温 $30^{\circ} \mathrm{C}$, 気圧は $102 \mathrm{kPa}$ であったので, 各風速におけるレイノルズ数を計算すると， 第 2 表のようになる. 計測した空力係数は揚力係数 $C_{\mathrm{L}}$, 抵 抗係数 $C_{\mathrm{D}}$, 重心周りの縦摇れモーメント係数 $C_{\mathrm{M}}$ である.

\section{2 .5 実験結果および考察}

(1) ノーズ形状比較 : 第 9 图に,ノーズ形状を比較した結 果を示す. 横軸は迎角で, 縦軸は揚力係数, 抵抗係数, 重心 周りのモーメント係数を示す. 図は風速 $30 \mathrm{~m} / \mathrm{s}$ の結果で, 実線がコーン型の場合 (cn と表示), 破線が半球型の場合 (semi と表示) を示し, 2 次の回帰曲線もグラフ中に示し た .また $\pm 6 \%$ エラーバーもプロットした ((5)参照). 揚力係 数は迎角 $40^{\circ}$ の時に半球型の方が $10 \%$ 程度高くなっている が, 弚れ以外は有意な差が見うけられない. 抵抗係数は半 球型の方がどの迎角でも $15 \%$ 程度の増加となっている．し かし, 大迎角時に起こる機体振動に関しては, 半球型ノー ズ模型の方が , コーン型模型に比べて小さかった . 着地点 の安全性を考えると半球型ノーズの方が優れているが, よ り高高度 , 長距離の飛行を目指す場合には , コーン型の方 か有利であるといえる .

(2) ヴォルテックス・ジェネレータの効果: 第 10 図に , ヴォ ルテックス・ジェネレータ装着の有無による空力係数の比 較図を示す (風速 $30 \mathrm{~m} / \mathrm{s}$ ) . 実線がコーン型ノーズの結果 で, 破線がヴオルテックス・ジェネレータを装着したコーン 型ノーズの結果である. 揚力係数と抵抗係数はヴオルテッ クス・ジェネレータ装着に伴い, 3〜 5\%程度増加している。 モーメント係数は, 光の負傾斜が末装着機体よりも減少し， モーメント係数の絶対值も迎角 $40^{\circ}$ で $14 \%$ 減少した .これ は, ヴォルテックス・ジェネレータに空気力が作用し, 空

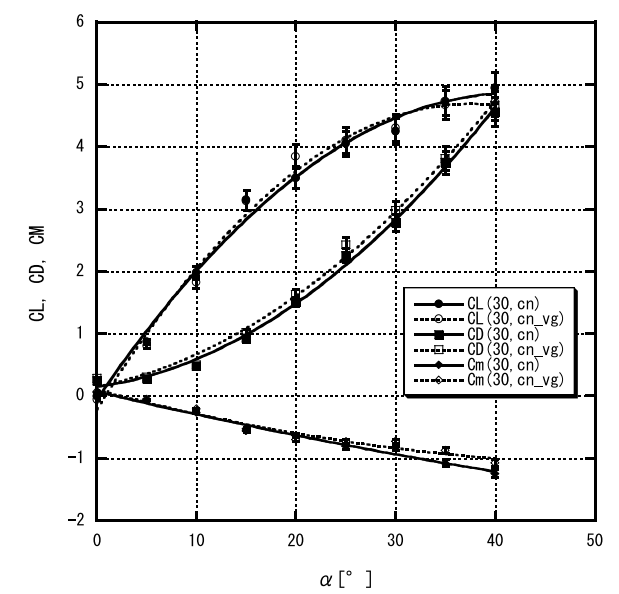

第 10 図 ヴォルテックス・ジェネレータの効果 (コーン型)

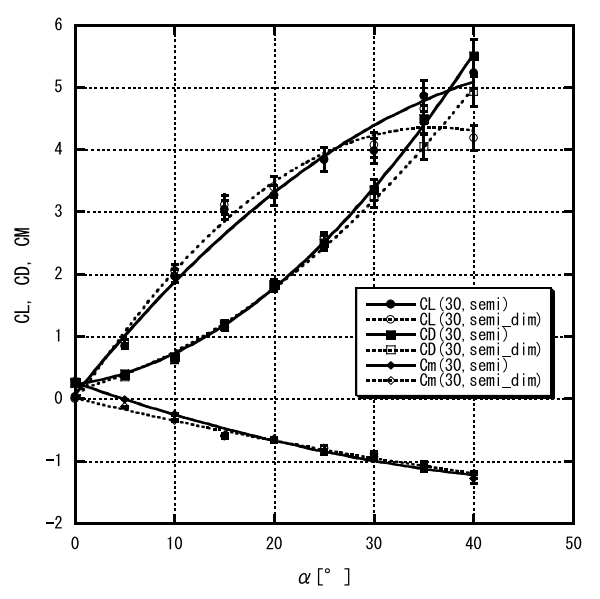

第11図 ディンプルの効果 (半球型)

カ中心が前方に移動したことに起因するもので, 機体姿勢 の安定性が悪くなっているといえる . しかし, 通風中の模 型の樣子を観察すると, ヴォルテックス・ジェネレータを 装着した模型は大迎角時に背面の非対称剝離渦によって生 じる機体の振動が押さえられていた .これは，ヴオルテッ クス・ジェネレータのような細かな突起物により，剝離渦 が拡散・小型化したことによると考えられる. 飛行中の機 体振動が低減するということは, 水ロケットの飛行安定性 か増すことになるため, ヴォルテックス・ジェネレータの 装着は, より安定な飛行を目指す場合には有効であるとい える (実際に飛行させた結果でも確認することができた) . 半球型ノーズの場合も同樣な傾向がみられた .

(3) ディンプルの効果 : 第 11 図に半球型ノーズにディン プルを施した場合の空力係数の比較を示す (風速 $30 \mathrm{~m} / \mathrm{s}$ ). 実線は, 半球型ノーズの結果を, 破線はディンプルを施した 半球型ノーズの場合の結果を示す . 揚力係数をみると , ディ ンプルを施した場合には迎角が $30^{\circ}$ 以上になると，通常の 場合に比べて揚力の増加率が小さなり，抵抗係数も 5 〜 $10 \%$ 減少している．これは，迎角か増すほどノーズ部背面 にディンプルが露出することにより，ディンプルの効果が 顕著になったからであると考えられる. 半球型のノーズを 


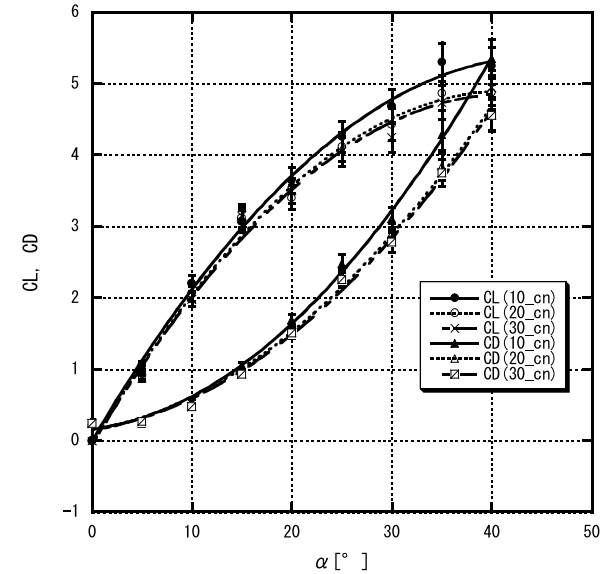

第 12 図 風速による違い (コーン型)

第 3 表 理論值との比較（抵抗係数）

\begin{tabular}{llcl}
\hline 風速 $(\mathrm{m} / \mathrm{s})$ & 10 & 20 & \multicolumn{1}{c}{30} \\
\hline 抵抗係数 (実験値) & 0.243 & 0.253 & 0.238 \\
抵抗係数 (理論値) & 0.226 & 0.224 & 0.229 \\
差異 (\%) & 7 & 13 & 4 \\
\hline
\end{tabular}

採用すると，コーン型のノーズより抵抗が増加してしまう ので , ディンプルを用いて抵抗を減少させるという使い方 が有効であるといえる .

(4) 風速による違い: 第 12 图にコーン型ノーズ模型を 使用した場合の，風速による空力係数の違いを比較した 图を示す.揚力および抵抗係数に関して，風速を $10 \mathrm{~m} / \mathrm{s}$ $\left(R e=3.01 \times 10^{5}\right), 20 \mathrm{~m} / \mathrm{s}\left(R e=6.02 \times 10^{5}\right), 30 \mathrm{~m} / \mathrm{s}$ $\left(R e=9.03 \times 10^{5}\right)$ の結果を示す . 図からわかるように， $10 \mathrm{~m} / \mathrm{s}$ の結果が , 迎角が大きくなるにつれて他の 2 ケース と異なる傾向を示している.滑らかな円柱や球は，レイノル ス数が $2 \sim 3 \times 10^{5}$ 程度から乱流への遷移が起こるので, 風速 $10 \mathrm{~m} / \mathrm{s}$ の場合か活乚流遷移の始まり， $20 \mathrm{~m} / \mathrm{s}$ および $30 \mathrm{~m} / \mathrm{s}$ の場合か活流域にあると考えられる .このような傾向は他 の実験条件でも見うけられた .

実際の水口ケットの飛行に照らし合わせて考えると，初 気圧が 5 気压の場合には最高速度が $25 \mathrm{~m} / \mathrm{s}$ 程度なので, 水 ロケット周りの流れはほほ乱流域にあるといって良い，一 方, $10 \mathrm{~m} / \mathrm{s}$ 以下では大迎角時の抵抗係数が大きくなること から，なるべく高い初速度で打ち上げることが重要である ことがいえる

(5) 計測データの誤差について : 本実験で利用した風洞試 験装置では, 無風時と通風時の模型の吊り線にかかる張力 を計測して，光の差から空力係数を算出している. 今回使 用した模型は, PET ボトルのサイズを基準に製作してい るので, 利用した風洞に比して模型の大きさは小さめであ り，通風時と無風時の張力差は $10^{-1} \mathrm{~N}$ のオーダーであっ た . 張力を測定するロードセルの計測誤差を, 読み取り誤 差と校正誤差を含めて最大 $\pm 2 \%$ 程度とすると, 空力係数 には $\pm 6 \%$ 程度の誤差となって表れるので, これを図中にエ ラーバーとして示した .

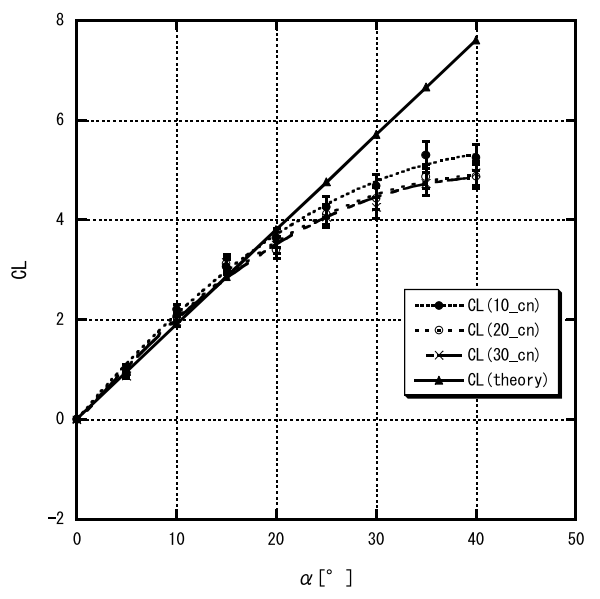

第 13 図 理論值との比較 (揚力係数)

2.2.6 理論值との比較 風洞実験で得られた空力係数の 値を，2.1で述べた細長物体理論によって計算された值と 比較する .

(1) 抵抗係数 : 抵抗係数は式 (1) を用いて計算する. 摩擦 係数は, $10 \mathrm{~m} / \mathrm{s}$ では遷移領域の值, $20 \mathrm{~m} / \mathrm{s}$ および $30 \mathrm{~m} / \mathrm{s}$ では乱流の值を用いた . 第 3 表にコーン型ノーズの模型に

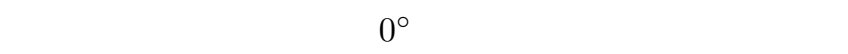
$7 ， 13 ， 4 \%$ となった .この速度範囲は，ちょうど境界層が 層流から乱流へと遷移する過程であり，正確な理論值の算 出も難しい . 実験值の誤差範囲も考えると, 風速 $20 \mathrm{~m} / \mathrm{s}$ の ケース以外はほぼ妥当な值であるといえる．

太田らの論文 ${ }^{11)}$ では, 水ロケットの最適飛行条件を推算 する際に，抵抗係数として 0.4 を用いているが，本実験お よび理論解析の結果と比べると，大きすぎるといえる．た だ，迎角が $10^{\circ}$ 前後の場合には抵抗係数が 0.4 程度となる

(2) 揚力係数 : 揚力係数は, まず式 (5) で揚力傾斜を計算 し , コーン型ノーズの模型の実験值にあてはめた . 結果を 第 13 図に示す. 迎角が $15^{\circ}$ 程度までの線形領域では理論 解析によって算出された揚力傾斜 $\left(C_{\mathrm{L} \alpha}=0.19\right)$ とほぼ一 致する.しかし, 弚れ以降の迎角では, フィンや胴体にお ける流れの剝離か影響して非線形性を示している.

\section{3. 水ロケットの設計パラメータの 飛行安定性への影響検討}

水口ケットの飛行安定性を向上させるためには, 水ロケッ 卜の飛行安定性に影響を及ぼす因子を考え，少の影響が最 小限になるような設計をする必要がある．これは，ロバス 卜設計の概念と通ずるものがあるため，本論文ではロバス 卜設計の手法を水ロケットの飛行安定性に影響を及ぼす因 子の評価に適用してみた . ロバスト設計では, 性能に影響 を与える因子のうち，制御可能な設計パラメータを制御因 子，管理や調整ができない因子を誤差因子 (ノイズ) と呼 び，光れらの性能への影響を実験的に調べる．ロバスト性 の評価は SN 比を用い, 要因効果図を作成して最適条件を 決定する．ここでは空力設計に関する因子と，構造設計に 関する因子を取り上げ, 弚の安定性への寄与について評価 


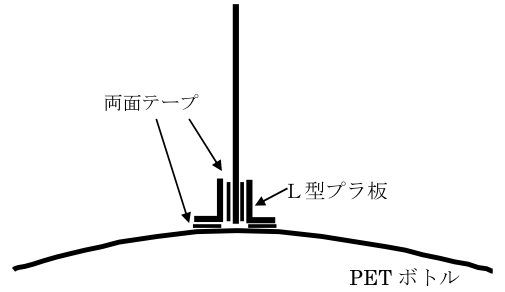

第14図フィンの取り付け (補強型)

するために行った実験結果について報告する．

3.1 制御因子 制御因子としては, 以下の要因を取り 上げた .

(1) 静安定余裕 : 機体姿勢の復元性に関連する要素で, 無 誘導ロケットでは,一般的に $15 \%$ 以上が要求される.しか し，水口ケットでは飛行中の質量中心の移動が大きいため， 空虚時の静安定余裕を多少多めにとり $20 \%$ 以上とることに している.ここでは, 静安定余裕を $15 \%$ (A1)，20\% (A2)， $25 \%$ (A3) と変えて性能を評価することにした . 静安定余 裕の変更は, ノーズ内部に付けた紙粘土の質量を調整する ことによって行った . 兴の際, 機体質量を統一させるため， 重心部にプラスティック板を巻き付けて各機体における質 量を調整した .

(2) ノーズ形状 : ノーズ形状として, 半球型 (B1) とコー ン型 (B2) を選んだ . 風洞実験結果から, 半球型の方がコー ン型に比べて揚力と抵抗が大きく, 飛行性能としてはコー ン型の方が有利であることがわかっている．しかし，飛行 安定性に関しては, 改めて検証してみる必要がある.

(3) フィンの岡性: フィンの岡性を, 1 重のボール紙 $(\mathrm{C} 1)$, 2 重のボール紙 (C2)，根元だけ 2 重にしたボール紙 (C3) の 3 種類用意した . ボール紙とは市販品で, 厚さが約 $1 \mathrm{~mm}$ である。

(4) ヴオルテックス・ジェネレータ: 風洞実験では, モーメ ント係数の值・傾斜に変化がみられたため, 飛行安定性に 関して調べる必要がある .ここでは，取り付けなし (D1)， 1 列取り付け (D2)，2 列取り付け (D3) の機体について調 べることにした .

(5) フィン取り付け剛性: 従来型のフィン取り付け方法 (第 2 図) と補強したフィン取り付け方法 (第 14 図) の比較を 行った . 補強方法は, 図のようにL 字型のプラスティック 板を両面テープによって取り付けた .ただし，この因子の 評価は他の 4 つの因子の比較とは別に評価した .

3.2 誤差因子 誤差因子としては, 意図的に製作誤差 を入れて実験を行ってみたが，別の効果（例えば，ロール による安定性の向上) が生じて, 正確な評価ができなかっ たので，実験時の風の状態を取り上げることにした .

3.3 飛行実験 飛行実験は, 制御因子を組み合わせた直 交表に基づいて行った.評価基準としては, 水ロケットの着 地点の打ち上げ方向からのずれ (偏角) を用いた . 水ロケッ 卜の飛行は風の影響を大きく受けるが, 風は定常風と非定 常風とに分離でき, 定常風の影響は有推力中およびコース ティング飛行中に対して理論的に補正可能である ${ }^{12)}$. 非定
第 4 表 飛行安定性に関する要因効果表

\begin{tabular}{|c|c|c|}
\hline 制御因子 & パラメータ & SN 比 $(\mathrm{dB})$ \\
\hline \multirow[t]{3}{*}{ 静安定余裕 } & $15 \%(\mathrm{~A} 1)$ & 17.28 \\
\hline & $20 \%$ (A2) & 18.33 \\
\hline & $25 \%$ (A3) & 21.19 \\
\hline \multirow{2}{*}{ ノーズ形状 } & 半球型 (B1) & 19.11 \\
\hline & コーン型 (B2) & 16.38 \\
\hline \multirow[t]{3}{*}{ フィン岡性 } & 1 重 (C1) & 19.42 \\
\hline & 2 重 (C2) & 18.55 \\
\hline & 半 2 重 (C3) & 18.84 \\
\hline ヴォルテックス & なし (D1) & 19.47 \\
\hline \multirow{2}{*}{ ジェネレータ } & 1 列 (D2) & 20.32 \\
\hline & 2 列 (D3) & 17.01 \\
\hline
\end{tabular}

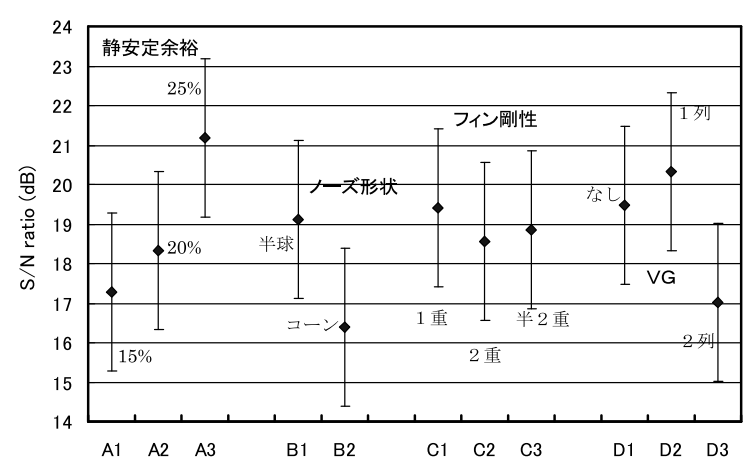

第 15 図飛行安定性に関する要因効果図

常風は外的ノイズ (誤差因子) として取り上げるので, 風 の穏やかな日と, 変動が激しい日を選んで, 弚の影響を評 価することとした．実際には定常風と非定常風を正確に分 離するのは難しかったが, 定常風は打ち上げ地点における 風速の 1 分間の平均值をとり, 非定常風は瞬間風速と平均 風速との差をとった . また , 確認のため実験は 2 回行った .

3.4 飛行安定性の評価結果 第 4 表に SN 比で評価し た結果 (要因効果表) を, 第 15 図に光のグラフ (要因効果 図）を示す.基準軌道からの偏角のばらつきが小さいほど， 高い SN 比になる . ロバスト設計における SN 比は $2 \mathrm{~dB}$ 程 度の変動が起こり，これを超えると有意な差があるとされ ている5). 実際の実験結果でも，1〜2 dB 程度の変動が起 こったので, 第 15 図中に $\pm 2 \mathrm{~dB}$ のエラーバーを示した . 以下, 結果を要約する。

(1) 静安定余裕 : 数值が大きくなるにつれて安定性も増す ことがわかる .

(2) ノーズ形状 : 半球型の方が良い結果となった . 抵抗係 数でみれば半球型はコーン型に比べて不利であったが, 大 迎角時の機体振動が半球型の方が小さかったことか飛行軌 道の安定化につながったと考えられる. 着地時の安全性も 考慮すれば, 半球型ノーズの方か総合的には優れていると いえる。

(3) フィン岡性 : $\mathrm{SN}$ 比の差が $1 \mathrm{~dB}$ 以内であり, 有意な差 とはいえない．1 枚フィンでも十分ではあるが, 取り付け 部の剛性を確保するために半 2 重のフィンを使うことか望 ましい.

(4) ヴオルテックス・ジェネレータ : 2 列装着の場合だけ 
安定性が悪くなることがわかった .これは , ヴォルテック ス・ジェネレータに作用する空気力が大きくなり，空力中 心が前方に移動して重心位置に近くなるため, 風洞試験で 確認したような安定性の減少が強く表れたと考えられる.

(5) フィン取り付け岡性 : 上記 4 つの評価項目とは別に実 験を行った結果, 従来型の取り付け方法に対して, 補強し た取り付け方法は SN 比が $2.69 \mathrm{~dB}$ 増加した。

以上をまとめると, 静安定余裕: $25 \%$,ノーズ形状: 半球 型, フィン: 半 2 重 (取り付け部強化型), ヴォルテックス・ ジェネレータ : 1 列装着という機体が, 飛行軌道の安定性 にとっては望ましい構成となる.実際，この構成により水 ロケットを製作し，これまで標準としてきた水ロケットと 比較実験を行ったところ，SN 比が $11.41 \mathrm{~dB}$ から $20.49 \mathrm{~dB}$ へと大幅に改善した . 最適機体の SN 比は $\mathrm{A} 3$ 機体の SN 比 $21.19 \mathrm{~dB}$ と比べて小さいが, これは実験実施日の風の状態 が A〜D の機体を調べた日と最適機体の実験日で異なるこ とに起因すると考えられる . 水ロケットの軌道は非定常風 に対して特に敏感で, 評価結果としての SN 比には $\pm 2 \mathrm{~dB}$ 程度の誤差は免れ得ない . 両者の差は $1 \mathrm{~dB}$ 以内であるた め, 誤差範囲内の結果であるといえる .

\section{4. 結論}

水口ケットの安定飛行を目指して, 空力係数の取得と空 カデバイスの検討，ロバスト設計手法の適用による安定機 体設計を行った，風洞実験の結果，水ロケット軌道解析に 必要な基礎空力データが得られた . ヴォルテックス・ジェ ネレータの装着は, 機体振動の減少に効果的であることが わかった . ディンプルの装着は大迎角時に抵抗を減少させ る効果か認められた .

ロバスト設計の手法を応用して, 飛行安定性に与える設 計パラメータの評価を行った。关の結果, 半球型ノーズで フィンは半 2 重の取り付け部強化型, ヴォルテックス・ジェ ネレータ 1 列装着という機体構成か飛行安定性にとって良 いとされ, 確認実験の結果, 飛行安定性が大幅に改善され た .ただ , 今回は評価のためのロバスト設計の手法を部分
的に適用したことに留まったが，この方法が安定性評価に 有効であることがわかったので, 今後最適化設計のための 設計評価を行ってみる必要があると考えている．

これらの解析により，水ロケットを教育用教材として用 いる場合に, 誰が作っても安定に飛行し安全に楽しめる機 体か製作できるようになった．実際にイベントの際に適用 して良い結果を得ている。

研究に際し，PET ボトルを大量に御寄付いただいた(株) 吉野工業所に感謝する次第である．また，風洞実験に協力 いただいた東京大学工学部航空宇宙工学科 久保田弘敏教 授，綿貫忠晴殿に感謝の意を表する．また，実験に関わっ た武蔵工業大学学生 (当時) 清水 大氏, 陰山 淳氏, 安 達篤史氏，豊岡 直氏，佐々木昇氏の協力に感謝する．

\section{参 考 文 献}

1) 冨田信之, 渡辺力夫 , 竹前俊昭 : 水ロケットによる科学技術教 育システムの開発，日本機械学会 2003 年度年次大会講演論文集 (V) , 2003, pp. 393-394.

2) 渡辺力夫, 冨田信之, 竹前俊昭 : 水ロケットの推力特性制御の一 方法, 日本航空宇宙学会論文集, 51 (2003), pp. 314-320.

3) 斎藤雄一: 無誘導ロケットの飛行特性に関する研究, 平成 8 年度 武蔵工業大学卒業論文, 1997 .

4) 仲野 亮, 冨田信之, 藤岡政俊, 町田豊隆: 画像処理による水口 ケット軌道の観测，日本機械学会 2003 年度年次大会講演論文集 (V) , 2003, pp. 387-388.

5) 田口玄一: 品質工学講座(1), (3), 日本規格協会, 東京, 1988 .

6) 上野憲造: 機能性評価による機械設計, 日本規格協会, 東京, 1995.

7) 小橋安次郎, 宮沢政文 : 二段式ロケット飛しょう体の揚力および 圧力中心推定法 , NAL-TM 30,1964 , pp. 1-72.

8) 豊岡 直: 無誘導ロケットの低速領域における空力特性に関する 研究, 平成 13 年度武蔵工業大学卒業論文, 2002 .

9) 藤岡政俊 : 無誘導ロケットの軌道計測システムに関する研究, 平 成 13 年度武蔵工業大学卒業論文, 2002 .

10) 大池敦夫, 青木克巳, 山口清大 : ゴルフボールのディンプル数 に対する飛翔特性と流れ, 東海大学工学部紀要, 41 (2001), pp. 99-103.

11) 太田貴之, 梅村 章: 水ロケットにおける飛行最適条件の研究, 日本航空宇宙学会論文集, 49 (2001), pp. 382-387.

12) 清水 大: 無誘導液体ロケットのロバスト設計に関する研究, 平 成 14 年度武蔵工業大学修士論文, 2003. 